Economic Instruments of Security Policy 


\title{
ECONOMIC InSTRUMENTS OF Security Policy
}

\author{
Influencing Choices of Leaders
}

Second Edition

Gary M. Shiffman and James J. Jochum

\section{palgrave macmillan}




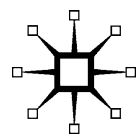

ECONOMIC INSTRUMENTS OF SECURITY POLICY

Copyright (C) Gary M. Shiffman and James J. Jochum, 2006, 2011.

All rights reserved.

First edition published in the United Kingdom in 2006 by

PALGRAVE MACMILLAN, Houndmills,

Basingstoke, Hampshire RG21 6XS.

Second edition published in the United States in 2011 by

PALGRAVE MACMILLAN ${ }^{\circledR}$-a division of St. Martin's Press LLC,

175 Fifth Avenue, New York, NY 10010.

Where this book is distributed in the UK, Europe and the rest of the world, this is by Palgrave Macmillan, a division of Macmillan Publishers Limited, registered in England, company number 785998, of Houndmills, Basingstoke, Hampshire RG216XS.

Palgrave Macmillan is the global academic imprint of the above companies and has companies and representatives throughout the world.

Palgrave ${ }^{\circledR}$ and Macmillan ${ }^{\circledR}$ are registered trademarks in the United States, the United Kingdom, Europe and other countries.

ISBN 978-0-230-11062-5 ISBN 978-1-137-12362-6 (eBook)

DOI $10.1057 / 9781137123626$

Library of Congress Cataloging-in-Publication Data

Shiffman, Gary $M$.

Economic instruments of security policy : influencing choices of leaders / Gary M. Shiffman, James J. Jochum. — 2nd ed.

p. $\mathrm{cm}$.

1. International economic relations-Political aspects. 2. National security-Economic aspects. 3. Terrorism-Prevention-Case studies. I. Jochum, James Joseph, 1965- II. Title.

HF1359.S54285 2010

$327.1^{\prime} 11-\mathrm{dc} 22$

A catalogue record of the book is available from the British Library.

Design by Newgen Imaging Systems (P) Ltd., Chennai, India.

Second edition: January 2011

109876654321

Transferred to Digital Printing in 2011 


\section{Contents}

Foreword to the Second Edition vii

Acknowledgments ix

Introduction $\quad \mathrm{xi}$

Part I The Individual 1

1 States Don't Make Decisions; People Do 3

2 The Economics of Autocracies 19

3 Principles for Policy Makers 39

Part II The World 47

4 Castro's Cuba and U.S. Sanctions 49

5 Democracies and the Politics of Trade 77

6 Money and Finance as Security Tools 113

7 Exchange Rate Choices and National Security 123

8 Maximizing over Time through Lending and Borrowing 139

9 Curing Poverty Helps National Security 165

10 Tools against Terrorists 181

11 International Law and Courts 191

Conclusion 203

Appendix 205

Notes 209

Index 223 


\section{ForeWORD TO THE SECOND EDITION}

Since the publication of Economic Instruments of Security Policy, the global economic landscape has experienced a monumental shift. Like never before, today's headlines are filled with references to sovereign debt, monetary policy, exchange rates, and debates about the role of the U.S. economy in the world. Topics likely considered "arcane" or "academic" in nature by the students of yesterday are now debated regularly within governments around the world. The principles discussed in Economic Instruments have come alive through real-life events, which enlighten the student but also create havoc in global financial markets by leading to rising unemployment, an unprecedented loss of private wealth, and sovereign defaults.

While the economic backdrop to the book has changed since its publication, the threats to global and national security discussed in the book remain real and urgent. At this writing, the world's major powers continue to grapple with how to prevent states like Iran from developing nuclear weapons and which instruments are best able to prevent states from failing and becoming havens for further terrorist activities. In short, the threats to our peace, stability, and prosperity were not put out of business by the Great Recession. The question which gave rise to this second edition of Economic Instruments is whether the financial tools available to fight these threats remain relevant and useful in this new economic environment.

Case studies, which formed the core of Economic Instruments, have been enhanced and updated to reflect emerging issues that challenge today's policy makers. Many of these case studies come directly from the personal experience of the authors. Toward this end, James Jochum joins this second edition as coauthor. In addition to being an adjunct professor of security and economics at Georgetown University and American University, Professor Jochum has played a significant role in developing and implementing many of the financial tools discussed herein. The reader of the second edition will benefit from 
our combined experience as both senior government policy makers and teachers of the next generation.

A principal theme of Economic Instruments is that the policy maker can craft more effective policies if one pays heed to the immutable laws of human nature. The Great Recession-as with all crises-revealed the best and worst of human nature. The effective policy maker will take the lessons learned from recent events and incorporate them into new policies to mitigate the threats of the future. The second edition of Economic Instruments provides the policy maker with the necessary tools to do so. 


\section{ACKNOWLEDGMENTS}

Jim Jochum wishes to acknowledge: my wife Rita, daughter Elena, and parents Gary and Donna Jochum, for their consistent support of my twisting, turning career. My great bosses, who taught me the ways of Washington and much more: Senator Chuck Grassley, Senator Phil Gramm, and Secretary Don Evans. I fear that I took more from you than I gave in return. My colleagues in academia who had the faith in me to allow me into a classroom and begin the process that led to this book: in particular, my coauthor Dr. Gary Shiffman, Dr. Rick Cupitt, Dr. Maria Cowles, Dr. Dan Byman, and Dr. Shoon Murray. My friends and colleagues who have contributed to my courses at Georgetown and American University and to this book in innumerable ways: Grant Aldonas, Matt Borman, Marguerite Trossevin, Andrew Shore, Tim Keeler, Clay Lowery, and Karan Bhatia. To the civil servants at the Department of Commerce's Export Administration and Import Administration, thank you for your patience (with me), expertise, public service, and professionalism. I truly enjoyed the time I spent with you. My business partners at Jochum, Shore \& Trossevin PC who graciously allowed me the time to work on this project, including Reza Karamloo who contributed directly to the content of this book. Lauren Lotko, for her intellectual contribution, attention to detail, and her diligence in keeping us on schedule. Our great editors at Palgrave Macmillan for their support and assistance. Frankie the French Bulldog, my constant and faithful companion during the writing of this book.

Gary Shiffman thanks all of those acknowledged in the first addition, the Georgetown University Center for Peace and Security Studies graduate students who taught him so much over the past seven years, coauthor Jim Jochum, and our research assistants Lauren Lotko and Holly Ghali. And thanks to my family for continued support, you are awesome. 


\section{INTRODUCTION}

"It is all about money-you economists are right," a friend and respected national security expert once quietly remarked. But who said economics was all about money? People often believe economics and national security intersect when discussing wealth, the velocity of the money supply, or derivative valuation in financial markets. While economists often work with these issues, the science of economics deals with people: people making choices, and the incentives and constraints that shape those choices. Think of the many decisions you make during the day: how many of those decisions are about money? Are you choosing to read this book because of money? Are you interested in security policies because of money? For most students we teach, the career choice to enter the security field applies to the mission and importance of security. Whether addressing the marketplace for goods and services, or political choices with global security consequences, individuals make the decisions. The individual seeks to maximize something-sometimes political power, sometimes money.

Economics, when applied to national security, remains a science of decision-making - an individual maximizing something (wealth, power, etc.) while facing resource and institutional constraints (democratic or autocratic checks on power, etc.). The United States did not decide to walk out on the Soviet Union at the 1986 Reykjavik Summit; Ronald Reagan walked away. Saddam Hussein, the individual leader of the political entity called Iraq, made the choice to invade Kuwait in 1990. Commander-in-Chief Bill Clinton decided to launch cruise missiles toward Sudan, Bosnia, and Iraq. George W. Bush chose to invade Iraq, and Barack Obama surged U.S. troops into Afghanistan in his first year in office. In statecraft, the stakes are not always this high, but individual people face choices and make decisions. Economic instruments employs economic analysis to understand how people make decisions related to national security. Through this micro approach-looking at the individual-we get meaningful analysis of the macro challenges and trends that define the great security debates of the day. 
Institutions, such as the form and function of government, cultural norms, and religious practices, place constraints on the decisions of national security decision makers. Beyond individual decision making by leaders, this book analyzes the economic tools of national security by dissecting the decision-making process within institutional constraints provided by political systems. In our work in Washington, D.C., both inside and outside government, we have had the opportunity to identify specific, recurring influences on decision making in a democracy. We have also studied the patterns of decision making in autocracies-dictatorships-whose closed economies and political systems exhibit distinctly different, complex structures. Such systems include totalitarians, tyrants, and individual despots; they also include military juntas and benevolent monarchs. And like democracies, autocratic institutions impose limits on the behaviors of leaders.

Applying economic analysis-individuals maximizing something within resource and institutional constraints-to national security policy making yields economic tools of security policy. By pinpointing the constraints, alternatives, and goals of a security decision maker, we can understand, and then predict, the economic instruments that will change behavior. Policy makers can then craft and evaluate appropriate initiatives and responses to advance their own goals.

This book presents the aforementioned ideas in two parts. Part I of the book describes the theoretical tools for building economic instruments of security policy. No knowledge of economics is required to understand the intuition of this section, but economists will appreciate the full technical details. In addition, the first section ends with a summary of economic principles for national security policy. Part II of the book describes numerous economic instruments employed by policy makers today and contains a number of case studies. To have meaning for policy makers, the analytical method we develop in part I must stand up to real-world situations. We use actual events to explain the theories throughout most of this book.

We begin each chapter with a diagram that posits the ensuing discussion in the overall framework for applying economic instruments to national security policy making. The building blocks for this framework are shown in figure I.1.

At the base is the economic actor-human nature. Chapter 1 deconstructs the inherent characteristics of all people; this nature forms the foundation of economics. Only by understanding the person behind the curtain can you understand Oz. If we want to sway the man at the controls, we must direct our policies at the person. 


\begin{tabular}{|c|c|c|c|c|c|}
\hline $\begin{array}{l}\text { Sanctions } \\
\text { (Ch. 4) }\end{array}$ & $\begin{array}{l}\text { Trade } \\
\text { (Ch. 5) }\end{array}$ & $\begin{array}{l}\text { Finance } \\
\text { (Chs. 6-8) }\end{array}$ & $\begin{array}{c}\text { Aid } \\
\text { (Ch. 9) }\end{array}$ & $\begin{array}{l}\text { Other... } \\
\text { (Chs. 10\& 11) }\end{array}$ & Policy Level \\
\hline \multicolumn{2}{|c|}{ Democracy } & (Ch. 2) & \multicolumn{2}{|c|}{ Autocracy } & Institutional Level \\
\hline \multicolumn{5}{|c|}{ Economic Actor (Ch.1) } & Individual Level \\
\hline
\end{tabular}

Figure I.1

The institutions within which the actors face constraints comprise the middle section. Institutions within a democracy, or within a dictatorship, can vary greatly, and there is a myriad of government institutions in the gray area between the extremes. So keep in mind that as we refer to either democracy or dictatorship, the types of each can also vary greatly. By taking an in-depth look at different types of dictatorships, chapter 2 demonstrates that institutional differences matter when crafting economic and security policies.

The third chapter ends the first part of the book by summarizing certain aspects of the individual and institutional levels of economic analysis, providing the reader with a basic tool kit for thinking about the rest of the chapters.

We begin part II by testing the analytic method we developed in the first three chapters against a specific case study on sanctions using a theoretical model, data, and empirical regression analysis. Specifically, we will examine a detailed case study of Fidel Castro's decisions while running Cuba in the context of U.S. unilateral sanctions targeting him from 1994 to 1999, to test our understanding of how to craft policies aimed at autocracies. No knowledge of regression is necessary to appreciate this in-depth application of an economic instrument-sanctions - to security policy making. Chapter 5 looks at the institutional functioning of a free market democracy, takes the United States as a case study, and examines the policies and politics of trade as a tool of security policy. Chapters 6,7 , and 8 address international finance and tools, such as monetary policy, exchange rates, and sovereign debt. Chapter 9 examines the link between poverty and national security to better inform aid and foreign assistance programs to advance security policies. Chapter 10 looks at recent, evolving economic tools against terrorists and terrorist organizations. The final chapter looks to international law for tools to apply 
economic pressures to decision makers to influence behavior important to national security.

The authors hope that readers will uncover fresh insights into the nexus of security policy making and economics as a rigorous academic discipline. New capabilities for shaping the world of the future by influencing the actions of leaders emerge as we combine real-world experience with the insights provided by economic analysis. We invite the reader to learn from our experiences by reading ahead. 